\title{
Bronchiectasis: Diagnostic Accuracy of Chest Computed Radiography ${ }^{1}$
}

\author{
EungYeop Kim, M.D., Boo-KyungHan, M.D., TaeSung Kim, M.D., JungHwa Hwang M.D., \\ Jung Hwan Yoon, M.D., Chul H. Paik, Ph.D., Kyung Soo Lee, M.D., Jae Min Cho, M.D., \\ SangHeeChoi, M.D., HyeKyungYoon, M.D.
}

Purpose : The aim of this study was to assess the diagnostic accuracy of chest computed radiography for the detection of bronchiectasis diagnosed by high-resolution CT.

Materials and Methods : Our study included 100 consecutive patients with bronchiectasis and 20 normal subjects, all seen on high-resolution CT. Two independent observers analyzed chest computed radiographs and recorded the presenceand type of bronchiectasis, and theinvolved lobe.

Results : On high-resolution CT, bronchiectasis was seen in one lobe in 29 patients, two lobes in 29, three lobes in 16, four lobes in 14, five lobes in 10, and six lobes in two. The bronchiectasis was tubular in 55 patients, mixed tubular and cystic in 29, and cystic in 16. For observer 1, the sensitivity, specificity, and accuracy of chest computed radiography was $95 \%, 85 \%$, and $93 \%$, respectively, while for observer 2 , the corresponding figures were $93 \%, 85 \%$, and $92 \%$. Sensitivity and specificity for observer 1 were $33 \%$ and $96 \%$ for the right upper lobe (46\% and 95\% for observer 2), 68\% and $86 \%$ for the right middle lobe $(76 \%$ and $86 \%), 70 \%$ and $78 \%$ for the right lower lobe (48\% and $83 \%$ ), $50 \%$ and $100 \%$ for the left upper lobe (50\% and $97 \%$ ), $63 \%$ and $90 \%$ for the lingular segment ( $49 \%$ and $93 \%$ ), and $87 \%$ and $75 \%$ for the left lower lobe (75\% and $90 \%$ ), respectively. Tubular bronchiectasis involving a single lobe was the most common source of false negative readings based on the findings of chest computed radiography.

Conclusion : Because chest computed radiography is not inferior to high-resolution CT for the detection of bronchiectasis, the routine use of chest computed radiography in screening for bronchiectasis is feasible. However, due to its low sensitivity in detecting bronchiectasis in a specific lobe, preoperative high-resolution CT examination may beneeded.

Index words : Bronchiectasis

Radiography, computer-assisted

Computed tomography (CT), thin-section

Bronchiectasis is an important cause of chronic cough,

${ }^{1}$ Department of Radiology, Samsung M edical Center, Sungkyunkwan University School of Medicine

Received August 4, 1998; Accepted January 15, 1999

Kyung Soo Lee, M.D., Department of Radiology, Samsung M edical Center, Sungkyunkwan University School of Medicine

\#50, Ilwon-Dong, Kangnam-Ku, Seoul, 135-710, Korea.

Tel. 82-2-3410-2511, FAX. 82-2-3410-2559,

email. kslee@smc.samsung.co.kr recurrent infection, and hemoptysis (1). For optimal treatment of a patient with bronchiectasis, its extent must be determined, especially when surgical resection is considered (2). Because tubular dilatation of airways can be seen in asthma, and bronchial dilatation associated with acute infection may subside, it is also important to know the type of bronchiectasis. 
Because radiographic features are nonspecific, it is difficult to make a definitive diagnosis of bronchiectasis on the basis of chest radiographic findings. The reported accuracy of chest radiographs for the diagnosis of bronchiectasis has varied between $63 \%$ and $93 \%(3,4)$.

At present, high-resolution CT with a reported diagnostic accuracy of $87-95 \%$, is the modality of choice for the diagnosis of bronchiectasis $(5,6)$. Because it is currently the diagnostic gold standard for the detection of bronchi ectasis, few studies have compared its diagnostic accuracy with that of chest radiography (7).

The purposes of our study were to assess the overall diagnostic accuracy of chest computed radiography for the detection of bronchiectasis diagnosed by high-resolution CT and to test the feasibility of chest computed radiography for the depiction of bronchiectasis in each lobe of thelung.

\section{Materials and Methods}

This study included 100 consecutive patients in whom bronchiectasis had been diagnosed and 20 normal subjects. All findings were based on the results of high-resolution CT scans obtained between September 1995 and August 1997. Fifty-eight patients were men and 42 were women, ranging in age from 18 to 80 years (mean, 44 years). Age-adjusted normal subjects (range, 21- 69 years; mean, 46 years) were those in whom highresolution CT scans revealed no abnormalities of the thorax. In normal subjects, CT scans were performed on suspicion of either bronchiectasis or interstitial pneumonia. The cause of bronchiectasis was postinfectious in all patients except one, in whom it was caused by ciliary dyskinesia syndrome. The patients $(n=100)$ complained of cough $(n=100)$, sputum $(n=100)$, hemoptysis $(n=47)$, and dy spnea $(n=27)$. Thirty one $(31 / 100$, $31 \%$ ) patients were smokers (mean, 16-pack years) and seven (7/20, 35\%) normal subjects were smokers (mean, 17-pack years). Chest computed radiographs and CT scans were obtained within 0 to 239 days of each other (mean, 14.5 days; in $52 \%$ of patients, studies were obtained within one week of each other). When two or more CT scans were obtained in one patient, the most recent scans were selected for evaluation and comparison with chest computed radiographs.

All CT scans were obtained using a HiSpeed Advantage Scanner (GE M edical Systems, Milwaukee, Wis., U.S.A.). Thin-section (1-mm collimation) CT scans were obtained through the thorax at $10-\mathrm{mm}$ intervals and at end inspiration. Additional expiratory thin-section (1-mm collimation) CT scans were obtained at $30 \mathrm{~mm}$ intervals through the thorax for the evaluation of air trapping. The scans were reconstructed using a bone al gorithm. Both mediastinal (width, $400 \mathrm{HU}$; level, - 50 $\mathrm{HU}$ ) and lung (width, 1,500 HU; level, - $700 \mathrm{HU}$ ) window images were printed. All chest computed radiographs were obtained using a Fuji computed radiography system (FCR 9000; Fuji, Tokyo, Japan) and, image parameters for computed radiography were as follows: 183-cm film-focus distance, 12:1 oscillating grid, and phototimed exposure. The default mode of image processing was used, including dynamic range compression, gradation enhancement, and edge enhancement; gradient amount $(\mathrm{GA})=0.9$, gradient type $(\mathrm{GT})=\mathrm{E}$, gradient center $(G C)=1.6$, gradient shift $(G S)=-0.2$, enhancement frequency $(R N)=4$, enhancement type $(R T)=R$, enhancement factor $(R E)=0.5$, DR frequency $(D R N)=2$, DR type $(D R T)=B, D R$ factor $(D R E)=0.6$. Chest images were depicted as single format by a 14" $\times$ 17" laser-printed hard copy. Both posteroanterior (PA) and lateral radiographs were obtained in 102 patients and PA radiographs only in 18.

High-resolution CT scans were evaluated retrospectively by two experienced chest radiol ogists who took no part in the assessment of chest computed radiographs. These radiologists assessed the CT scans together and decisions were reached by consensus. They recorded the presence, type, and location of bronchiectasis, which was considered to be present when at least one of the followings was noted: lack of tapering of a bronchus, dilated bronchi abutting the mediastinal pleura, internal diameter of bronchi greater than that of the adjacent pulmonary artery, visualized bronchi within 1$\mathrm{cm}$ of the parietal pleura, and mucus-filled dilated bronchi (8). When bronchiectasis was present, it was divided into three types: tubular, cystic, or mixed tubular and cystic. Its location was classified into six lobes with the lingular segment of the left upper lobe as a separate lobe.

Chest computed radiographs were observed by two independent chest radiologists who did not participate in CT evaluation. One observer (observer 1) had four years experience of interpreting chest computed radiographs, and the other (observer 2 ) had two years experience. They recorded the presence and type of bronchiectasis, and the involved lobe. Thelingular segment of left upper lobe was al so considered as a separate lobe. Bronchiectasis was considered to be present 
when at least one of the following findings was noted: bronchovascular bundle crowding associated with lobar or segmental volumeloss, tram-track appearance of dilated bronchi, mucoid impaction, cystic lung lesion with or without air-fluid level, and ring-like lesions (4).

Interobserver agreement as to the presence of bronchiectasis in each patient and each lobe was anal yzed using Kappa statistics. For each set of readings, sensitivity, specificity and accuracy of chest computed radiography for the diagnosis of bronchiectasis were cal culated, as were diagnostic accuracy in each lobe and the frequency of findings suggestive of bronchiectasis, as seen on chest computed radiographs.

\section{Results}

High-resolution CT showed that bronchiectasis was present in one lobe in 29 patients, two lobes in 29, three lobes in 16, four lobes in 14, five lobes in 10, and six lobes in two on high-resolution CT. It was of tubular type in 55 patients, mixed tubular and cystic in 29, and cystic in 16.

The most common finding of bronchiectasis observed on chest computed radiographs was bronchovascular bundle crowding associated with lobar or segmental volume loss (91\% [181/200]). The other findings were tram-track appearance of dilated bronchi (49\% [98/200]) (Fig. 1), ring-like lesions (39\% [77/200]), cystic lung lesion with or without air-fluid level (29\% [58/200]), and mucoid impaction (8\% [16/200]).

For observer 1, the sensitivity, specificity, and accuracy of chest computed radiography were $95 \%, 85 \%$, and $93 \%$, respectively; for observer $2,93 \%, 85 \%$, and $92 \%$, respectively. Interobserver agreement as to the presence of bronchiectasis in a given patient was good ( $\mathrm{k}=$ $0.61)$ and was al so good in a given lobe $(k=0.40-0.65)$ (Table 1). Sensitivity and specificity for observer 1 were $33 \%$ and $96 \%$ for the right upper lobe $(46 \%$ and $95 \%$ for observer 2), $68 \%$ and $86 \%$ for the right middle lobe (76\% and $86 \%$ ), $70 \%$ and $78 \%$ for the right lower lobe (48\% and $83 \%$ ), $50 \%$ and $100 \%$ for the left upper lobe (50\% and $97 \%$ ), $63 \%$ and $90 \%$ for the lingular segment (49\% and $93 \%$ ), and $87 \%$ and $75 \%$ for the left lower lobe ( $75 \%$ and $90 \%$ ), respectively (Table 1 ).

A total of 14 undetected bronchiectatic lesions were present in one lobe in eight patients $(57 \%)$, in two lobes in five (36\%), and in three lobes in one (7\%). Twelve (86\%) of the 14 fal se-negative readings occurred in cases of tubular bronchiectasis and the remaining two (14\%) in cases of cystic bronchiectasis. On chest computed radiographs, tubular bronchiectasis involving a single lobe (eight of 14 false negative readings) was the most diffi-

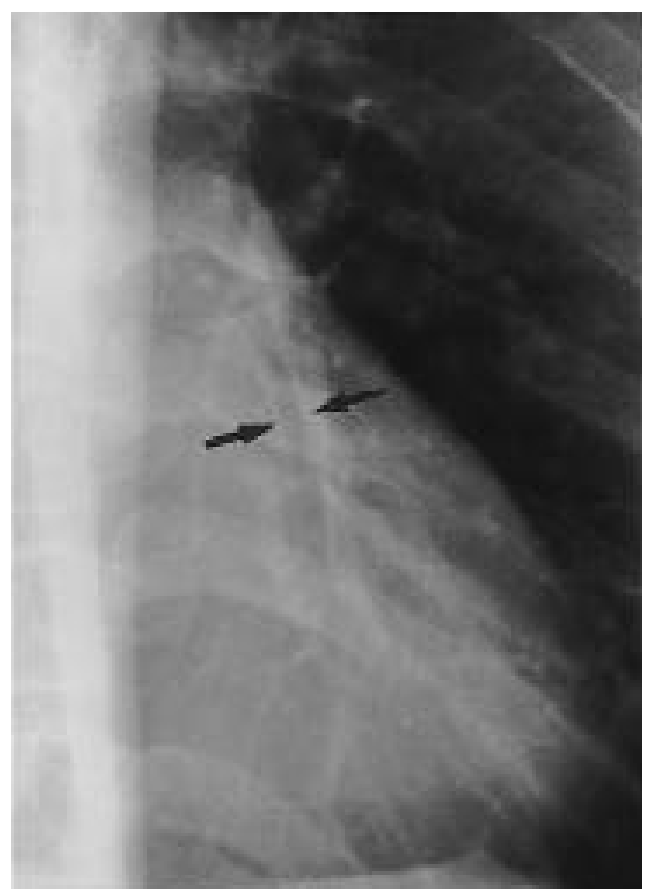

A
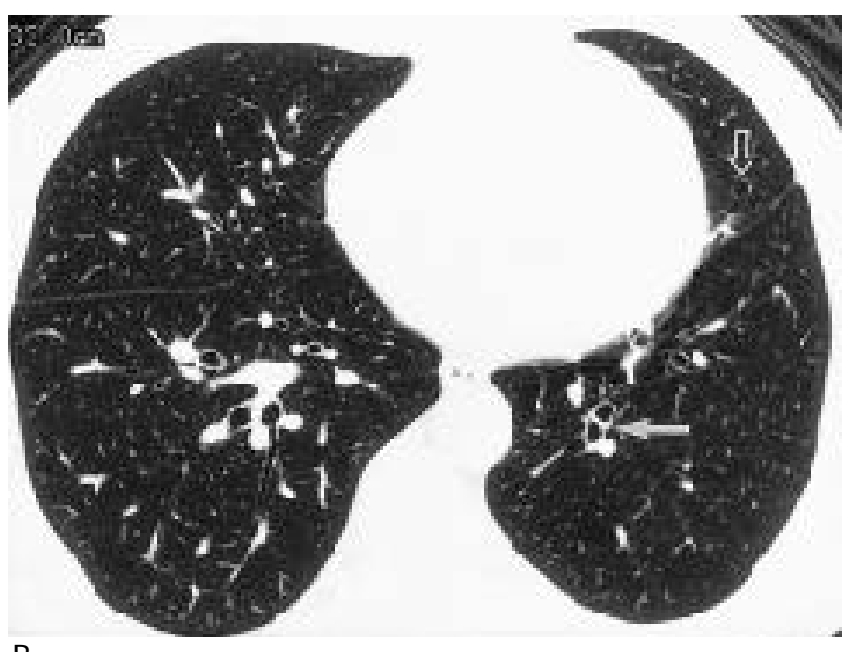

Fig. 1. Typical feature of tubular bronchiectasis on chest computed radiograph in 49-year-old man

A. Posteroanterior radiograph shows tram lines (arrows) in theleft retrocardiac area. Both observers read radiograph as positive for bronchiectasis in the left lower lobe.

B. Lung window of thin-section (1-mm collimation) CT scan obtained below the level of inferior pulmonary vein shows slightly di lated bronchi in theleft lower lobe (arrow) and the lingular segment of the left upper lobe (open arrow). Both observers missed bronchiectasis in thelingular segment of the left upper lobe. 
cult to detect (Fig. 2). One of the two missed cystic bronchiectatic lesions was present in the right middle lobe with surrounding pulmonary emphysema. The other cystic bronchiectatic lesion was local ized in the lingul ar segment of the left upper lobe.

Eight (20\%) of 40 readings in six normal subjects were false positive for bronchiectasis. In these cases, the intervals between chest computed radiographs and HRCT scans were 0 day in 4 normal subjects, 3 days in one, and 81 days in one. For both radiologi sts, readings in two normal subjects were false positive (no interval between chest computed radiographs and HRCT scans). In one there were parenchymal bands (Fig. 3), and in one, both hemidiaphragms were el evated. In the remaining four false-positive readings in four normal subjects, the lungs were normal on high-resolution $\mathrm{CT}$ and the causes of false positivity were unclear.

\section{Discussion}

Prior to the advent of high-resolution CT, which is currently the first choice of diagnostic modal ity for the detection of bronchiectasis, bronchography had been considered the gold standard. Common plain radiographic findings are peribronchial fibrosis, increased size and number of bronchovascul ar markings by retained secretions, bronchial crowding, loss of lobar or lung volume, ring-like lesions (honeycombing), cystic lung lesion with or without air-fluid level, and mucoid impaction (4). However, these findings except cystic lung lesion and mucoid impaction are nonspecific (9). In our study, the most common chest computed radiographic finding was bronchovascular bundle crowding associated with lobar or segmental volumeloss (91\%).

Table 1. Sensitivity, Specificity, and Accuracy of Chest Computed Radiography in the Detection of Bronchiectasis for Each Lobe

\begin{tabular}{|c|c|c|c|c|c|c|c|c|c|c|c|c|}
\hline & \multicolumn{2}{|c|}{ RUL } & \multicolumn{2}{|c|}{ ULRML } & \multicolumn{2}{|c|}{ RLL } & \multicolumn{2}{|c|}{ LUL } & \multicolumn{2}{|c|}{ Ling } & \multicolumn{2}{|c|}{ LLL } \\
\hline & Ob1 & Ob2 & Ob1 & Ob2 & Ob1 & Ob2 & Ob1 & Ob2 & Ob1 & Ob2 & Ob1 & Ob2 \\
\hline Sensitivity & $\begin{array}{l}33 \% \\
(8 / 24)\end{array}$ & $\begin{array}{c}46 \% \\
(11 / 24)\end{array}$ & $\begin{array}{c}68 \% \\
(42 / 62)\end{array}$ & $\begin{array}{c}76 \% \\
(47 / 62)\end{array}$ & $\begin{array}{c}70 \% \\
(28 / 40)\end{array}$ & $\begin{array}{c}48 \% \\
(19 / 40)\end{array}$ & $\begin{array}{l}50 \% \\
(4 / 8)\end{array}$ & $\begin{array}{l}50 \% \\
(4 / 8)\end{array}$ & $\begin{array}{c}63 \% \\
(37 / 59)\end{array}$ & $\begin{array}{c}49 \% \\
(29 / 59)\end{array}$ & $\begin{array}{c}87 \% \\
(52 / 60)\end{array}$ & $\begin{array}{c}75 \% \\
(45 / 60)\end{array}$ \\
\hline Specificity & $\begin{array}{c}96 \% \\
(92 / 96)\end{array}$ & $\begin{array}{c}95 \% \\
(91 / 96)\end{array}$ & $\begin{array}{c}86 \% \\
(50 / 58)\end{array}$ & $\begin{array}{c}86 \% \\
(50 / 58)\end{array}$ & $\begin{array}{c}78 \% \\
(62 / 80)\end{array}$ & $\begin{array}{c}83 \% \\
(66 / 80)\end{array}$ & $\begin{array}{c}100 \% \\
(112 / 112)(\end{array}$ & $\begin{array}{c}97 \% \\
(111 / 112)\end{array}$ & $\begin{array}{c}90 \% \\
(55 / 61)\end{array}$ & $\begin{array}{c}93 \% \\
(57 / 61)\end{array}$ & $\begin{array}{c}75 \% \\
(45 / 60)\end{array}$ & $\begin{array}{c}90 \% \\
(54 / 60)\end{array}$ \\
\hline Accuracy & $\begin{array}{c}83 \% \\
(100 / 120)\end{array}$ & $\begin{array}{c}85 \% \\
(102 / 120)\end{array}$ & $\begin{array}{c}77 \% \\
(92 / 120)\end{array}$ & $\begin{array}{c}81 \% \\
(97 / 120)\end{array}$ & $\begin{array}{c}75 \% \\
(90 / 120)\end{array}$ & $\begin{array}{c}71 \% \\
(85 / 120)\end{array}$ & $\begin{array}{c}97 \% \\
(116 / 120)(\end{array}$ & $\begin{array}{c}97 \% \\
115 / 120)\end{array}$ & $\begin{array}{c}77 \% \\
(92 / 120)\end{array}$ & $\begin{array}{c}72 \% \\
(86 / 120)\end{array}$ & $\begin{array}{c}81 \% \\
(97 / 120)\end{array}$ & $\begin{array}{c}83 \% \\
(99 / 120)\end{array}$ \\
\hline K-value & & 60 & & 60 & & 40 & 0.6 & 65 & & .54 & 0.5 & \\
\hline
\end{tabular}

Note-RUL : right upper lobe, RML : right middle lobe, RLL : right lower lobe, LUL : left upper lobe (upper division only), Ling: lingular segment, LLL : left lower lobe, Ob1 : observer 1, Ob2 : observer 2, k-value: interobserver agreement

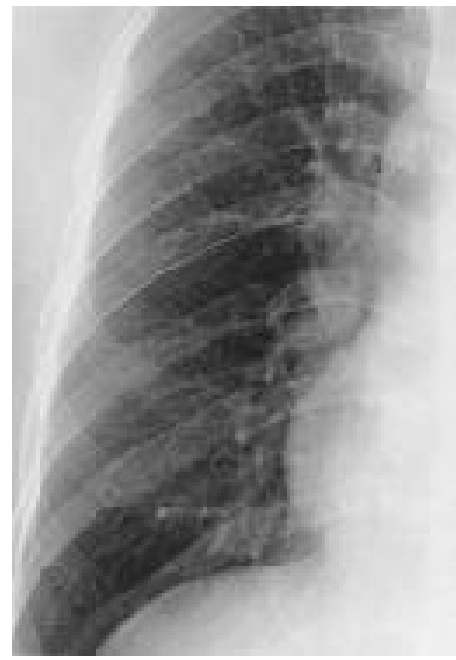

A

Fig. 2. False-negative reading on chest computed radiograph in 30-year-old man with tubular bronchiectasis

A,B. Posteroanterior (A) and lateral (B) radiographs show no evidence of bronchiectasis.

C. Lung window of thin-section (1-mm collimation) CT scan obtained at level of liver dome shows mucoid impaction in the dilated bronchus (arrow) in the posterior basal segment of theright lower lobe.

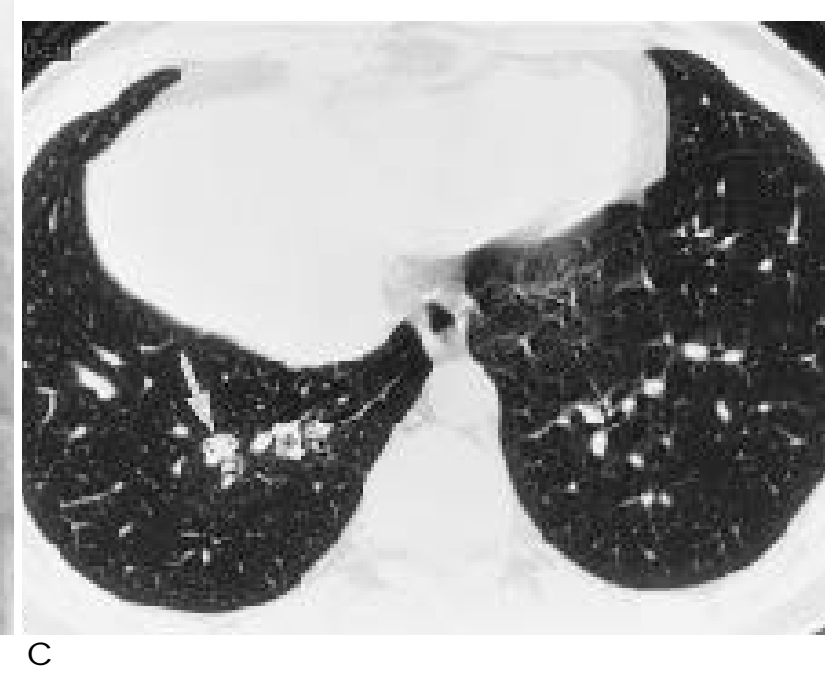



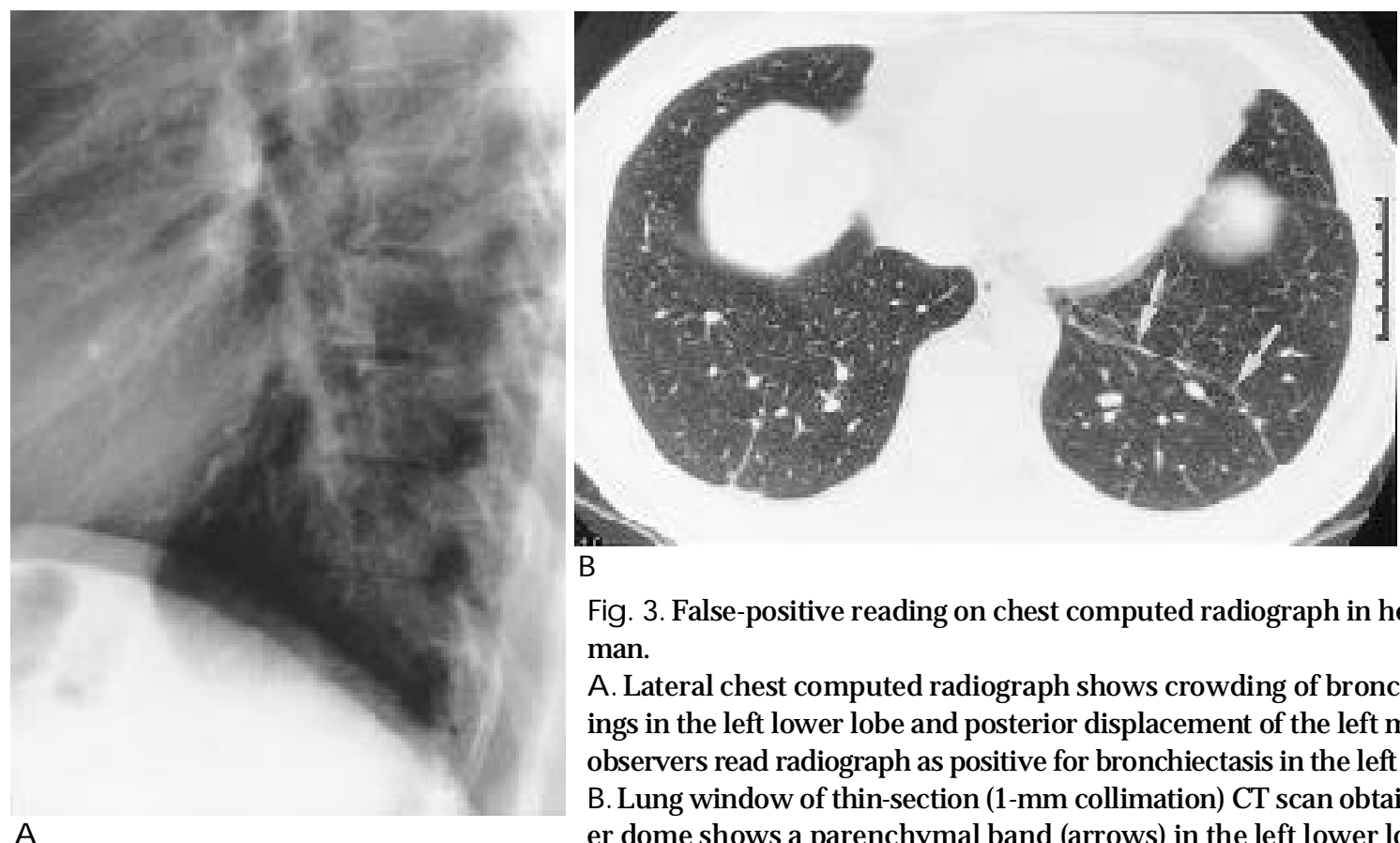

Fig. 3. Fal se-positive reading on chest computed radiograph in healthy 44 -year-old man.

A. Lateral chest computed radiograph shows crowding of bronchovascular markings in the left lower lobeand posterior displacement of the left major fissure. Both observers read radiograph as positive for bronchiectasis in the left lower lobe.

B. Lung window of thin-section (1-mm collimation) CT scan obtained at level of liver dome shows a parenchymal band (arrows) in the left lower lobe which caused crowding of bronchovascular markings on chest computed radiograph.

This is nonspecific and can be seen in other diseases including simple atelectasis without bronchiectasis. Tramtrack appearance of dilated bronchi (49\%), ring-likelesions (36\%), cystic lung lesion with or without air-fluid level (29\%), and mucoid impaction (8\%) were al so seen.

Thereported diagnostic accuracy of chest radiography for the detection of bronchiectasis varies. Cooke et al . (10) found that the sensitivity of chest radiography, compared with bronchography, was only $37 \%$, and the specificity, $95 \%$. In a study by Currie et al. (3), the sensitivity, specificity, and diagnostic accuracy of chest radiography in the detection of bronchographically-diagnosed bronchiectasis were $47 \%, 100 \%$, and $63 \%$, respectively. Recently, van der Bruggen-Bogaarts et al. (11) reported a sensitivity of $88 \%$ and specificity of $74 \%$ in chest radiography for the detection of high-resolution-CT-diagnosed bronchiectasis. In their study, chest radi ographs were obtained using a high-kil ovol tage technique (120 to $140 \mathrm{kV}$ ). Conversely, using a low-kilovoltage technique, Gudbjerg et al. (4) found that the diagnostic accuracy of chest radiography was $93 \%$. They found a normal chest radiograph in only $7 \%$ of 112 bronchographically proven cases of bronchiectasis. Given theinherent problem of the low-kilovoltage technique (narrow dynamic range), however, we do not believe that such a high accuracy can be achieved.

Sensitivity (observer 1 and observer 2, 93\% and 95\%, respectively), specificity ( $85 \%$ and $85 \%$ ), and accuracy
(92\% and $93 \%$ ) of chest computed radiography in the detection of bronchiectasis in our study are, to the best of our knowledge, higher than in previous reports $(3,11)$, and this may be partly due to the computed radiographic system used. In computed chest radiography, we applied postprocessing of dynamic range compression. In this type of compression, both peripheral pulmonary markings and mediastinal structures are clearly and simultaneously visualized on radiographs (12). The positive effect of dynamic range compression may lead to increases in the detection rate of bronchiectasis, especially in the retrocardiac portion of both lower lobes. Corroborative evidence of this is the fact that when the high-kilovol tage technique is used, the diagnostic accuracy of chest radiography is high. As with dynamic range compression, retrocardiac lower lobes are clearly visualized.

The high sensitivity of chest radiography noted in the studies of Gudbjerg (4) and van der Bruggen-Bogaarts et al. (11), and in ours, may suggest that chest computed radiography can be used as a screening tool in the diagnosis of bronchiectasis. Patients suffering from this condition usually undergo medical treatment, and diagnosis per se is important in the treatment of the disease. If, however, symptoms are severe or persistent and the disease is confined to a few bronchi, resection may be considered (13). Because of its low sensitivity in the detection of bronchiectasis in a specific lobe in our study, 
the use of high-resolution CT for preoperative evaluation may bejustified.

Bronchiectasis of the right middleand left lower lobe was most easily detected on chest computed radiographs (Table 1). Because the right middle lobe, surrounded by both major and minor fissures, is well defined anatomically, volume decrease or morphological change may be easily detected on chest computed radiographs. The enhanced visibility of left lower lobar volume through the heart shadow, as seen on computed chest radiographs, may have increased the detectability of bronchiectasis in this lobe.

In our study, the radiologists missed bronchiectasis in 14 of 200 readings (7\%). The 14 fal senegative readings were in cases involving one lobe in eight patients (57\%), two lobes in five (36\%), and three lobes in one (7\%). In addition, in 12/14 false-negative readings, bronchiectasis was of the tubular type, and tubular bronchiectasis involving a single lobe is therefore the most common source of false-negative readings in chest computed radiography.

Four of eight false-positive readings occurred in cases in which a parenchymal band was present or both hemi diaphragms were el evated. These results suggest that a parenchymal band or elevation of a hemidiaphragm, as seen on chest radiographs, can simulate bronchiectasis due to bronchovascular crowding with or without volume loss.

Our study suffers from certain limitations. One is the fact that the radiologists analyzed the radiographic findings of CT-diagnosed rather than pathologically diagnosed cases of bronchiectasis. Because CT scans are not a perfect di agnostic modality (sensitivity, 94\%- 96\%; specificity, 93\%-100\%) $(6,14)$, our results might not have reflected the trueaccuracy of chest computed radiography in the diagnosis of bronchiectasis. However, because surgery is performed in only a limited number of patients with bronchiectasis, and high-resolution CT is currently the diagnostic gold standard, our results may have some val idity in clinical situations. A second limitation is that because only bronchiectatic and normal patients were observed, differentiation between normal and abnormal radiographs may have been much easier. The inclusion of other radiographically similar conditions such as pulmonary fibrosis, atelecta- sis, chronic bronchitis, emphysema, or interstitial lung disease might have resulted in different levels of diagnostic accuracy.

In conclusion, chest computed radiography is not inferior to high-resolution $\mathrm{CT}$ in the detection of bronchiectasis. Because of its high accuracy, chest computed radiography can be used as a routine examination in the screening of patients with bronchiectasis, but its low sensitivity for a given specific lobe, compared to CT, may justify preoperative high-resolution CT examination.

\section{References}

1. Millar AB, Boothroyd AE, Edwards D, Hetzel MR. The role of computed tomography (CT) in the investigation of unexplained hemoptysis. Respir M ed 1992;86:39-44

2. McGuinness G, Naidich DP, Leitman BS, McCauley DI. Bronchiectasis: CT evaluation. AJR 1993;160:253-259

3. Etienne T, Spiliopoulos A, Megevend R. Bronchiectasis: indication and timing for surgery. Ann Chir 1993;47:729-735

4. Currie DC, Cooke JC, M organ AD, et al. Interpretation of bronchograms and chest radiographs in patients with chronic sputum production. Thorax 1987;42:278-284

5. Gudbjerg CE. Roentgenologic diagnosis of bronchiectasis: an analysis of 112 cases. A cta Radiol 1955;43:209-226

6. Kang EY, Miller RR, Muller NL. Bronchiectasis: comparison of preoperative thin-section CT and pathologic findings in resected specimens. Radiology 1995;195:649-654

7. Grenier P, Maurice F, Musset D, Menu Y, Nahum H. Bronchiectasis: assessment by thin-section CT. Radiology 1986; 161:9599

8. Kim JS, Muller NL, Park CS, Grenier P, Herold CJ. Cylindrical bronchiectasis: diagnostic findings on thin-section CT. A J R 1997; 168:751-754

9. Stanford W, Galvin JR. The diagnosis of bronchiectasis. Clin Chest M ed 1988;9:691-699

10. Cooke JC, Currie DC, M organ AD, et al. Role of computed tomography in diagnosis of bronchiectasis. Thorax 1987;42:272277

11. van der Bruggen-Bogaarts BA, van der Bruggen $\mathrm{HM}$, van Waes PF, Lammers JJ. Screening for bronchiectasis: a comparative study between chest radiography and high-resolution $\mathrm{CT}$. Chest 1996;109:608-611

12. Goodman LR, Wilson CR, Foley WD. Digital radiography of the chest: promises and problems. AJR 1988;155:1241-1252

13. Phillips MS, Williams M P, Flower CD. How useful is computed tomography in the diagnosis and assessment of bronchiectasis? Clin Radiol 1986; 37:321-325.

14. Joharjy IA, Bashi SA, Adbullah AK. Value of medium thickness CT in the diagnosis of bronchiectasis. A J R 1987; 149: 1133-1137 


\title{
기관지확장증 : 흉부전산화방사선촬영의 진단정확도 ${ }^{1}$
}

\author{
성균관대학교 의과대학 삼성서울병원 진단방사선과
}

\section{김응엽. 한부경. 김태성. 황정화· 윤정환 백철화· 이경수 조재민. 최상희. 윤혜경}

목적 : 고해상전산화단층촬영 (HRCT) 에서 진단된 기관지확장증에 대한 흉부 전산화 방사선촬영 (CR) 의 진 단 정확도를 알아보고자 하였다.

대상 및 방법 : HRCT에서 진단된 기관지확장증 환자 100 명과 정상 20 명을 대상으로 하였다. 두 명의 방사선과 의사가 독자적으로 흉부 $\mathrm{CR}$ 을 분석하고 기관지확장증의 존재유무, 종류, 침범엽을 기록하였다.

결과 : HRCT에서 진단한 기관지확장증은 29 예에서 폐의 1엽, 29 예에서 2엽, 160 예에서 3엽, 140 예에서 4엽, 10예에 서 5엽, 2예에서 6엽에 있었다. 기관지확장증은 55예에서 관상형, 29예에서 관상형과 낭성 혼합형, 160 예에서 낭성 이었다. 기관지확장증의 진단에 있어서 흉부 CR의 전체적인 민감도, 특이도, 정확도는 제1관찰자에서 각각 $95 \%$, $83 \%, 93 \%$ 였고, 제2관찰자에서 각각 $93 \%, 85 \%, 92 \%$ 였다. 우상엽의 경우 민감도와 특이도는 제1관찰자에서 각각 $33 \%$ 와 $95 \%$ 였으며(제2관찰자에서 각각 $46 \%, 95 \%$ ), 우중엽의 경우 $68 \%$ 와 $86 \%$ ( $76 \%, 86 \%$ ), 우하엽의 경우 $70 \%$ 와 $78 \%$ (48\%, 83\%), 좌상엽의 경우 $50 \%$ 와 $100 \%$ (50\%, 97\%), 설분절(lingular segment)의 경우 $63 \%$ 와 $90 \%$ $(49 \%, 93 \%)$, 좌하엽의 경우 $87 \%$ 와 $75 \%(75 \%, 90 \%)$ 였다. 한 엽을 침범한 관상형 기관지확장증의 경우가 흉부 $\mathrm{CR}$ 에서 가장 흔한 가음성 판독의 원인이었다.

결론 : 기관지확장증의 진단에 있어서 흉부 $\mathrm{CR}$ 은 $\mathrm{HRCT}$ 의 진단 정확도에 근접하는 높은 정확도를 가지므로, 선별검사 목적으로 사용될 수 있다. 하지만, 특정 엽에서 진단의 민감도가 낮으므로 수술 전 HRCT 는 필요하다 고 생각한다. 